\title{
CORRESPONDENCE
}

\section{Price of Books}

SiR,- You recently asked me to review a book for Nature. I was tempted to remark in the review that the book was very expensive. Then it occurred to me that nothing happens when reviews include such perfunctory remarks, and that anyway most scientific books are very expensive now. This led to wider questions. Do scientific authors, publishers, printers or booksellers make more money than they deserve at the expense of the scientific community? Does the system of advertising, whereby piles of letters reach me each month, add a lot to the prices of books? Should we scientists organize ourselves to prevent our exploitation by others? We grumble about the cost of books but do nothing. It is tempting to blame the publishers, but I, for one, would not deny them a fair profit, even if they may have subsidized the scientific community in the past.

It so happens that the book I reviewed was one of a series. (I think the name of the publishers is unimportant, because their prices do not seem unusual.) So I have plotted the year against the

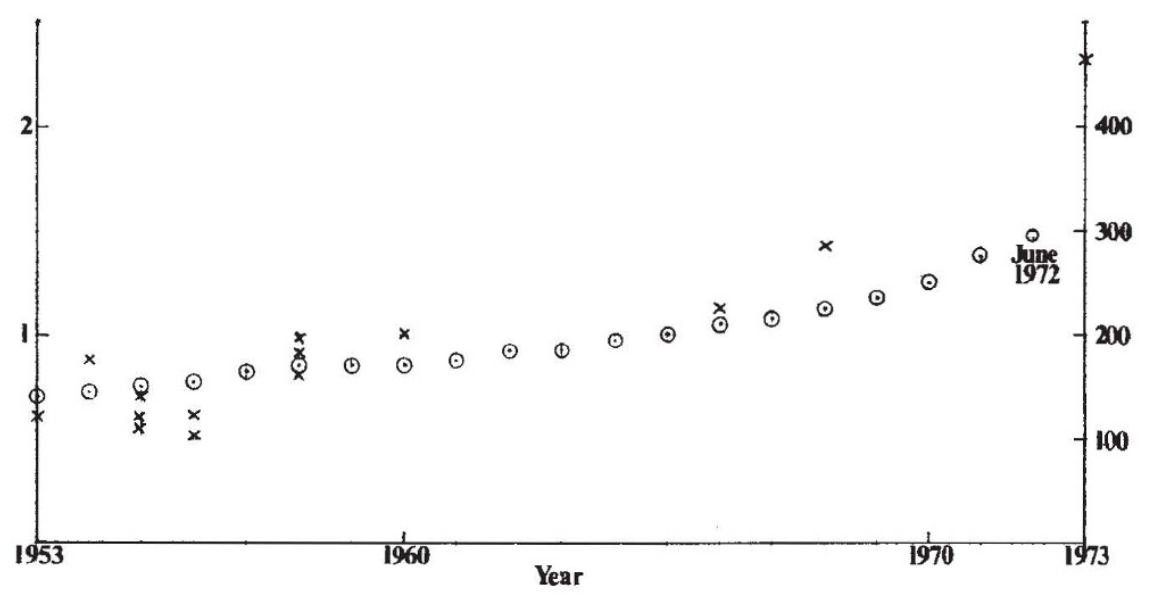

Fig. 1 Rise in book prices: $\times$, cost $(£)$ per 100 pages; $O$, index of retail prices (all items, $1947=100)$.

publication price per 100 pages of each book of the series and against the index of retail prices-all items (Fig. 1). One can dispute the implication that this affords a fair comparison between what a book should cost and what it does, but nonetheless I think two conclusions are clear: the costs of living and of books were fairly consistent until the end of the sixties; rampant inflation thereafter has affected books somewhat more than the cost of living. Should we organize a lobby, or be grateful that things are not worse than they are? Yours faithfully,

P. G. Drazin

School of Mathematics,

University Walk,

Bristol BS8 1TW

\section{Obituary}

\section{Richard J. Winzler}

GLyCOPROTEIN research, cancer research and biomedical education suffered a severe loss with the sudden death of Richard J. Winzler on September 28, 1972.

Winzler was born in San Francisco on September 29, 1914. He received his early education in the San Francisco area and obtained his $\mathrm{PhD}$ from Stanford University in 1938, at the age of 23. Following this he was Sterling Fellow at Yale University (1938-1939) and National Research Council Fellow at the Wenner Gren Institute, Stock. holm (1940-41). On the outbreak of the Second World War, Winzler returned to the USA to complete his NRC fellowship at the National Cancer Institute, Bethesda (1941-43). During this early period his interests began to change from considerations of metabolic reactions in normal cells, especially yeast, to studies of the biochemical changes which differentiate normal and malig. nant tissues.

Following these Wanderjahren,
Winzler was appointed Assistant Professor at the University of Southern California at Los Angeles in 1943 and rose through Associate Professor to Professor in 1949. In 1952 he was appointed Chairman of the Department of Biochemistry at the University of Illinois College of Medicine.

Throughout this period of increasing burdens in teaching and administration, Winzler maintained an active role in research, continuing his studies on normal and abnormal metabolism, including the role of thyroxine, but with a developing emphasis in the field of glycoproteins in which he was to make his major contributions. In particular, he recognized the widespread distribution of glycoproteins in serum, developed methods for their isolation and characterization, and began studies on their structure and biosynthesis. $\mathrm{He}$ realized that sialic acid was a major determinant of glycoprotein structure and that the glycoprotein levels varied in certain pathological states. It is from this early work that some of our recent understanding on the role of carbo- hydrate in glycoprotein function can be traced. At the same time Winzler continued his studies on biochemical changes in neoplastic tissue and extended these to studies of the biochemical effects of viral infections.

In 1965 Winzler accepted the position of Chairman and Professor at the Department of Biochemistry, School of Medicine, at the State University of New York at Buffalo. Despite the administrative burdens of extended planning for new medical, dental and research facilities this was probably the most productive period of his life, as his wide knowledge of glycoproteins became focused on the glycoproteins of cell membranes. A significant step forward in this area was made by his isolation of the major glycoproteins of the red cell membrane, their structural characterization and the elucidation of monosaccharide sequence in certain of their subunits. This led him to the development of a model for membrane glycoprotein structure, identical with that proposed at about the same time by Morawieki, in which the hetero- 
saccharide subunits are clustered toward one end of the polypeptide chain while the other end contains predominantly lipophilic residues serving to anchor the glycoprotein in the membrane. Subsequent studies have supported this model in erythrocytes and other cells.

In 1969 Winzler decided to free himself of the onerous administrative responsibilities of the chairmanship at Buffalo and, in order to devote more time to teaching and research, accepted a Professorship in Chemistry at Florida State University under the auspices of a National Science Foundation Development Grant. He entered into this new position with characteristic enthusiasm and was beginning to establish his research group with an increasingly strong emphasis towards the biosynthesis structure and function of the glycoprotein components of cell surfaces. This work was not completed.

Winzler was a Visiting Professor at the University of Wisconsin (1941), a Commonwealth Fellow at the University of Freiburg (1958) and a Consultant in Medical Education at the University of Chengmai, Thailand (1962). He served on the Editorial Boards of Cancer Research and of the Proceedings of the Society of Experimental Biology and Medicine, on several policy committees of the American Cancer Society and the National Institutes of Health, and on the Advisory Committee of the American Red Cross National Fractionation Center. One of his last contributions to determining future direction in biomedical research was in serving on the Planning Committee for the development of the Program Plan of the National Cancer Institute when it was elevated to the rank of Bureau with the National Institutes of Health.
Winzler could work in a laboratory with the enthusiasm and dedication of a graduate student. For a period of two weeks he worked in the writer's laboratory on the isolation of red cell ghosts in large amounts for his structural studies on the $\mathrm{M}$ and $\mathrm{N}$ antigens. $\mathrm{He}$ would work until late at night and cheerfully signed the receipts required by our supplier for the large purchases of sugar needed for agglomeration and washing to assure him that they were not being used for illicit fermentation.

Dick Winzler made major contributions in diverse areas of research, in the teaching of medical and dental students and scientists and in the administration and development of several medical schools and universities. $\mathrm{He}$ was widely respected as a teacher, a scientist and a friend and, with the approval of his wife, Janna, and their three children a memorial fund has been set up at Florida State University to promote an interest in biochemical research.

\section{Announcements}

\section{Reports und Publicanions}

not included in the Monthly Books Supplement

\section{Great Britain and Ireland}

Incorporated Soctety for Psychical Research. Annual Report of the Council and Statement of Accounts, Lctober 1971-30 September 1972. Pp. xxi. (London: Incorporated Society for Psychical Research, 1 Adam and Eve Mews, W8, 1973.) [263 Cosmatom, Vol. 1, No. 1, February 1973. (A Journal devoted to the Study of Five-Dimensional Space-Time-Mass, and to Consideration of the View 列 P.O. Box 12, 1973.) f1. [263, Medical Research Council Handbook 1972-1973. Pp. iv +268. (London: Medical Research Council. 1972.) $f 1$.
Local Government Boundary Commission for England. Report No. 2. Pp. iiit9. (London: HMSO, 1973.) 16p net. [273 Industrial Research and Development: The Report of the Committee of Enquiry into the Research Associations, 1972/3. Pp. 195. (London: Conference of Industrial Research Associations, 29/30 St. ames Strect, SW1, 1973.) $£ 3$. A Computer Simulation Model for Bus Operations Planning. By J. P. D. Gerrard and D. Brook Pp. 38. (Peterlee, County Durham: UK Scientific Centre, IBM United Kingdom Limited, 1972.) [283 Albright and Wilson, Ltd. Annual Report for
1972. Pp. 28. (London: Albright and Wilson, Ltd. 1972.) Pp. 28. (London: Albright and Wilson. Ltd.
[293 Southampton University Library. Occasional Paper No. 4: The Literature of Science and Technology Acy. Pp. 24 (Southampton: The University, Tur60n.
Bulletin of the British Museum (Natural History). Entomology. Vol. 27, No. 8: A Revision of the Lecanodiaspis Targioni-Tozzetti (Homoptera: Coccoidea) of the Ethiopian Region. By C. J. Hodgson. Pp. 411-452. f1.75. Vol. 28. No. 2: G. B. Buckton's Works on Aphidoidea (Hemoptera) By J. P. Doneaster. Pp. 23-109+6 plates. £3.55. Supplement 19: A Revisionary Classification of the Rutiliin (Diptera: Tachidniae), with Keys to the Described Species. By Roger Ward Crosskey. Pp. 167. £6.50 Zoology. Vol, 23. No. 5: The Gunong Benon Zonation of Birds and Marmist on and Altitunal By Lord Medway. Pp. 103-154. £2.05. Yon 24. No. 4: Spirorbinae (Serpulidae: Polychaeta) 24 South-Eastern Australia. A New Genus, Four New Subgenera and Seven New Species, By Phyllis KnightJubgenera and Pp. 229-259. $£ 1.25$. Vol, 24, No, 5: On the
Jones. Pp. Cyprinid Fish Barbus Allaudi Pcllcgrin; a Possible Intergeneric Hybrid from Africa. Studies on African Cyprinidae, Part 1. By K. E. Banister. Pp. 261$290+1$ plate. $£ 1.45$. Vol. 24 , No. 6: The Cyprinid Fishes of Acanthobrama Heckel and Related Genera. By M. Goren, L. Fishelson and $\mathbf{E}$. Trewavas. $\mathbf{P p}$. 291-315. f1.15. Supplement 4: Cardigan Bay, Recent Foraminifera (Cruises of the R.V. Antur, 1962-1964). By J. R. Haynes. Pp. $245+33$ plates. 1972 and 1973.) 1972 and 1973.) fessor Hans Molz. (An Inaugural Lerurc efor before the University of Oxford on 21 Novembe Oxford Un Unversity Press, 1973, 50p Press; London: The Child with Cerebral Palsy, Social, Emotiona and Educational Adjustment - an Annotated Bibliography. By Doria Pilling. Pp. 61. (London:
National Children's Bureau, 1 Fitzroy Square, W1, 1973.) $£ 1.25$.

\section{Other Countries}

The University of Adelaide. Centre for Precambrian Rescarch. Special Paper No. 1: Stratigraphic Problems of the Later Precambrian and Early Cambrian. Edited by J. B. Jones and B. Adelaide, Centre for Precambrian Research, 1972. SA2; SUS2.50; £1.

Publications of the Dominion Astrophysical $\mathrm{Ob}$ servatory, Victoria, BC. Vol. XIV, No. 4: Numeri cal Methods for Computing Stellar Line-Profiles and Continuum Fluxes. By J. B. Hutchings. Pp. 59-96. Vol. XIV, No. 5: The Spectroscopic Binary System H.D.11860. By A. H, Batten and B. Szcidl. PD 97-105. (Victoria, BC: Dominion Astrophysical

\section{HOW TO BUY NATURE}

The cost of one year's subscription to NATURE is :

$$
\text { UK \& elsewhere }
$$

US \& Canada

Nature (Friday)

$£ 16$

$£ 20$

Nature \& Nature Physical Science

or Nature New Biology

Nature New Biology or Nature Physical Science

All three editions

$£ 29.50$

£44

Index (1972)

f1

$\mathbf{f} 1.50$

(Charges for delivery by air mail on application). Subscribers in North America may be able to claim a tax rebate against their NATURE subscription.
Editorial, Advertising and Publishing Offices of NATURE

MACMILLAN JOURNALS LIMITED

4 LITTLE ESSEX SFREET, LONDON WC2R 3LF

Telephone Number: 01-836 6633. Telegrams: Phusis London WC2R 3LF Telex 262024

MACMILLAN JOURNALS LIMITED

711 NATIONAL PRESS BUILDING

WASHINGTON DC 20004

Telephone Number : 202-737 2355. Telex 64280

Advertisement Department

MACMILLAN JOURNALS LIMITED

4 LITTLE ESSEX STREET, LONDON WC2R 3LF

Telephone Numbers: UK 01-836 6633. USA 202-737 2355

Subscription Department

MACMILLAN JOURNALS LIMITED

BRUNEL ROAD, BASINGSTOKE, HANTS RG21 2XS

Telephone Number: Basingstoke 29242

Classified advertisements

T. G. SCOTT \& SON, LIMITED

1 CLEMENT'S INN, LONDON WC2A 2ED

Tolephone Number: 01-242 6264/01-405 4743

Tolegrams: Textualist London WC2A 2ED

Reglstered as a newspaper at the Post Office

Copyright (C) Macmillan Journals Limited, July 131973 